\title{
EFEKTIVITAS RIZOBAKTERI SEBAGAI PGPR UNTUK PERTUMBUHAN STEK DAUN TANAMAN HIAS PEPEROMIA TURBOENSIS
}

\section{EFFECTIVENESS OF RHIZOBACTERIA AS PGPR TO THE GROWTH OF LEAF CUTTINGS OF ORNAMENTAL PLANTS PEPEROMIA TURBOENSIS}

\author{
Uli Fermin ${ }^{1}$, Mirza Arsiaty Arsyad ${ }^{1}$, Waode Nuraida ${ }^{1}$, Rian Arini², Gusti Ayu Kade Sutariati ${ }^{1}$, \\ Tresjia Corina Rakian', La Mudi ${ }^{*}$ \\ ${ }^{1}$ Jurusan Agroteknologi Fakultas Pertanian Universitas Halu Oleo Kendari, Sulawesi Tenggara \\ ${ }^{2}$ Jurusan Proteksi Tanaman Fakultas Pertanian universita Halu Oleo Kendari, Sulawesi Tenggara \\ ${ }^{3}$ Program Studi Budidaya Tanaman Perkebunan Politeknik Pertanian Negeri Samarinda, Kalimantan Timur \\ *Email: lamudi89@gmail.com \\ * Corresponding Author, Diterima: 21 Des. 2021, Direvisi: 28 Jan. 2021, Disetujui: 9 Apr. 2021
}

\section{ABSTRACT}

This research was aimed to determine the response of various sources of leaf cuttings and the duration of soaking with rhizobacteria on the growth of Peperomia turboensis leaf cuttings. The study used a factorial completely randomized design consisting of two factors. The first factor is leaf cuttings, consisting of 3 levels, namely whole leaves (S1), 1/2 leaf base (S2), and 1/2 leaf tip (S3), while the second factor is the length of soaking the cuttings, consisting of 4 levels, namely without immersion (B0), immersion 4 hours (B1), immersion 8 hours (B2) and immersion 12 hours (B3), thus obtained 12 treatment combinations. Each treatment was repeated 3 times to obtained 36 experimental units. The variables observed included the duration of shoot emergence, the percentage of live and dead plants, the number of shoots, and root length. The research data were analyzed using analysis of variance. The results of the analysis showed that the real effect was followed by DMRT $\alpha=0.05$. The results showed that independently whole leaf cuttings gave the best results followed by $1 / 2$ leaf cuttings at the base. Meanwhile, based on the length of soaking with rhizobacteria, treatments with 4 and 8 hours of immersion gave the best results when compared to the length of soaking for 12 hours and without soaking treatment. For the best treatment interactions obtained in the treatment of whole leaves with 4 hours of immersion both in the observation of the number of shoots and root length.

Keywords: Soaking time, Peperomia turboensis, rhizobacteria, leaf cuttings.

\begin{abstract}
ABSTRAK
Penelitian ini bertujuan untuk mengetahui respon berbagai bahan stek daun dan lama perendaman dengan rizobakteri terhadap pertumbuhan stek daun Peperomia turboensis. Penelitian menggunakan rancangan acak lengkap pola factorial, terdiri dari dua faktor. Faktor pertama yaitu stek daun, terdiri dari 3 taraf yaitu daun utuh $\left(\mathrm{S}_{1}\right), 1 / 2$ daun bagian pangkal $\left(\mathrm{S}_{2}\right)$ dan $1 / 2$ daun bagian ujung daun $\left(\mathrm{S}_{3}\right)$ dan faktor kedua yaitu lama perendaman stek, terdiri dari 4 taraf yaitu tanpa perendaman $\left(\mathrm{B}_{0}\right)$, perendaman 4 jam $\left(\mathrm{B}_{1}\right)$, perendaman 8 jam $\left(\mathrm{B}_{2}\right)$ dan perendaman 12 jam $\left(\mathrm{B}_{3}\right)$ sehingga diperoleh 12 kombinasi perlakuan. Setiap perlakuan diulang 3 kali sehingga diperoleh 36 unit percobaan. Variabel yang diamati meliputi lama munculnya tunas, persentasi tanaman hidup dan mati, jumlah
\end{abstract}


tunas dan panjang akar. Data hasil penelitian dianalisis menggunakan analisis ragam. Hasil analisis yang menunjukkan pengaruh nyata dilanjutkan dengan uji DMRT ${ }_{a=0,05}$. Hasil penelitian menunjukkan bahwa secara mandiri stek daun utuh memberikan hasil terbaik kemudian diikuti oleh bahan stek $1 / 2$ daun bagian pangkal. Perlakuan lama perendaman dengan rizobakteri selama 4 dan 8 jam memberikan hasil terbaik bila dibandingkan dengan perendaman 12 jam dan tanpa perendaman. Interaksi perlakuan terbaik diperoleh pada perlakuan daun utuh dengan perendaman 4 jam baik pada pengamatan jumlah tunas dan panjang akar.

Kata kunci : Lama perendaman, Peperomia turboensis, rizobakteri, stek daun.

\section{PENDAHULUAN}

Tanaman hias peperomia adalah salah satu tanaman hortikultura yang saat ini banyak diminati oleh kalangan pencinta tanaman hias. Hal ini terlihat dari animo masyarakat pada kondisi saat ini terutama adanya pandemi Covid-19 yang mengharuskan orang bekerja dari rumah, sehingga menjadi pemicu utama semakin tingginya minat masyarakat untuk budidaya tanaman hias. Kesersediaan tanaman hias peperomia di Kota Kendari masih cukup langkah, kalaupun ada harganya relatif mahal, padahal tanaman ini cukup mudah diperbanyak meskipun membutuhkan waktu yang relatif lama. Tanaman hias peperomia umumnya dapat diperbanyak dengan biji dan stek daun. Perbanyakan dengan biji sangat sulit dilakukan sehingga kebanyakan diperbanyak dengan stek daun. Namun dalam perbanyakannya mengalami kendala yaitu lamanya pemunculan tunas dan tingginya intensitas tanaman yang mengalami kebusukan.

Oleh karena itu, salah satu strategi yang dapat dilakukan untuk mempercepat pemuculan tunas dan menghidari kebusukan tanaman dapat dilakukan dengan penggunaan PGPR (Plant Growth Promoting Rhizobacteria). Rizobakteri merupakan bakteri rizosfer yang mengoloniasi daerah perakaran yang berperan sebagai pamacu pertumbuhan tanaman
(Elango et al., 2013). Selain itu, rizobakteri juga dapat meningkatkan pertumbuhan tanaman melalui mekanisme yang berbeda (Chuks et al., 2018). Hasil penelitian Suatariati et al. (2018) melaporkan bahwa rizobakterimampu berperan sebagai pemacu petumbuhan tanaman. Penggunaan rizobakteri telah terbukti efektif meningkatkan perkecambahan (Mudi et al., 2019; Sutariati et al., 2020), pertumbuhan, dan hasil tanaman kedelai (Suarni et al., 2016; Sutariati et al., 2019).

Salah satu aplikasi rizobakteri yang efektifyaitu dengan cara perendaman pada benih atau stek. Perendaman benih dalam rizobakteri telah banyak dilaporkan efektif mempercepat pemunculan tunas tanaman jarak pagar (Advinda et al., 2018). Lebih lanjut, aplikasi rizobakteri juga mampu meningkatkan pertumbuhan dan hasil tanaman radichio (StanojkoviæSebiæ et al., 2018). Kemampuan rizobakteri tersebut berkaitan langsung dengan kemampuan rizobakteri yang menghasilkan hormon tumbuh berupa IAA, melarutkan fosfat dan memfiksasi nitrogen (Guyasa et al., 2018; Afa et al., 2020). Selain itu, rizobakteri juga dilaporkan terbukti efektif meningkatkan ketahanan tanaman terhadap penyakit tanaman. Penelitian ini relevan dengan penelitian sebelumnya bahwa penggunaan agens hayati mampu menekan kejadian penyakit tanaman (Silaban et al., 2015; Patel \& Saraf, 
2017; Flores-Gallegos \& Nava-Reyna, 2019). Berdasarkan konsep pemikiran tersebut, maka penelitian efektivitas rizobakteri sebagai PGPR untuk pertumbuhan stek daun tanaman hias peperomia perlu dilakukan. Tujuan yang ingin dicapai dari pelaksanaan penelitian ini yaitu untuk mengetahui respon berbagai sumber stek daun (bahan tanam) dan lama perendaman stek daun dalam rizobakteri terhadap pertumbuhan stek daun peperomia.

\section{BAHAN DAN METODE}

Penelitian ini dilaksanakan dari bulan Oktober sampai Desember 2020, di Laboratorium Agroteknologi Unit Agronomi Fakultas Pertanian Universitas Halu Oleo dan AgroPlant Nursery Perumahan Grand Boulevard Regency Blok I/197, Kendari. Alat yang digunakan pada penelitian ini adalah cawan petri, erlenmeyer, gelas kimia, jarum ose, lampu bunsen, autoclave, oven, laminar air flow, baki semai, spayer, shaker dan timbangan analitik. Bahan yang digunakan pada penelitian ini yaitu Bacillus sp. CKD061 (koleksi Prof. Dr. Ir. Gusti Ayu Kade Sutariati, M.Si.), tanaman hias Peperomia turboensis, TSB, media tanam (pupuk kandang sapi, sekam dan tanah), tissue, label, aluminium foil, plastik wrap, alkohol $70 \%$ dan aquades.

Penelitian menggunakan rancangan acak lengkap pola faktorial, terdiri dari dua faktor. Faktor pertama yaitu stek daun, terdiri dari 3 taraf yaitu daun utuh $\left(\mathrm{S}_{1}\right), 1 / 2$ daun bagian pangkal $\left(\mathrm{S}_{2}\right)$ dan $1 / 2$ daun bagian ujung daun $\left(\mathrm{S}_{3}\right)$ dan faktor kedua yaitu lama perendaman stek dengan rizobakteri, terdiri dari 4 taraf yaitu tanpa perendaman $\left(\mathrm{B}_{0}\right)$, Perendaman 4 jam $\left(\mathrm{B}_{1}\right)$, perendaman 8 jam $\left(\mathrm{B}_{2}\right)$ dan perendaman $12 \mathrm{jam}\left(\mathrm{B}_{3}\right)$, dengan demikian diperoleh 12 kombinasi perlakuan. Setiap perlakuan diulang 3 kali sehingga diperoleh 36 unit percobaan.

Penelitian diawali dengan persiapan bahan uji berupa tanaman hias $P$. turboensis yang diperoleh dari penjual tanaman hias di Kota Kendari dan bahan tanam tersebut dibawa ke lokasi penelitian. Selanjutnya dilakukan perbanyakan rizobakteri Bacillus sp. CKD061 dengan media TSA dan diinkubasi selama 48 jam. Koloni bakteri yang tumbuh disuspensikan dalam aquades steril hingga mencapai kerapatan populasi $10^{9} \mathrm{cfu} \mathrm{mL}^{-1}$ dan siap digunakan untuk pengujian.

Langkah selanjutnya persiapan media tanam dengan menggunakan campuran tanah, pupuk kandang sapi dan sekam bakar dan disterilisasi dengan autoclave pada suhu $121^{\circ} \mathrm{C}$ selama 15 menit pada 1 Atm. Selanjutnya ketiga media tersebut dicampur tanah : sekam : pupuk kandang sapi $(2: 1: 1)$ dan selanjutnya diisikan pada baki percobaan. Bahan stek yang telah diperoleh dicuci bersih dengan air mengalir, selanjutnya dicuci dengan alkohol $70 \%$ selama 2 menit lalu dicuci dengan aquades steril dan dikeringanginkan selama 30 menit. Selanjutnya stek daun diberi rizobakteri dengan volume $100 \mathrm{ml}$ setiap perlakuan, lalu direndam dengan lama perendaman sesuai perlakuan. Setelah perlakuan selanjutnya stek daun dikeringanginkan selama 30 menit. Setelah kering angin stek daun ditanam sesuai layout penelitian dan baki ditutup dengan plastik wrap untuk menjaga kelembaban media uji.

Variabel yang diamati pada penelitian ini meliputi: waktu munculnya tunas (hari), persentasi stek hidup (\%), persentasi stek mati (\%), jumlah tunas dan 
panjang akar $(\mathrm{cm})$. Data hasil penelitian dianalisis menggunakan analisis ragam. Hasil analisis yang menunjukkan pengaruh nyata dilanjutkan dengan uji Duncan Multiple Range Test á=0,05.

\section{HASIL DAN PEMBAHASAN}

Hasil penelitian efektivitas rizobakteri sebagai PGPR untuk pertumbuhan stek daun tanaman hias peperomia berpengaruh signifikan. Hasil uji DMRT pengaruh mandiri lama perendaman stek daun terhadap pengamatan lama munculnya tunas dan persentasi stek hidup disajikan pada Tabel 1 dan Tabel 2. Hasil DMRT pengaruh mandiri stek daun dan lama perendaman stek terhadap pengamatan persentasi stek mati disajikan pada Gambar 1a dan Gambar 1b. Hasil uji DMRT pengaruh interaksi stek daun dan lama perendaman terhadap jumlah tunas dan panjang akar tanaman peperomia disajikan pada Tabel 3. Performa panjang akar tanaman peperomia pada perlakuan bahan stek daun dan lama perendaman dengan rizobakteri disajikan pada Gambar 2.

Hasil penelitian pada Tabel 1 menunjukkan bahwa pengaruh mandiri stek daun terhadap waktu munculnya tunas tercepat diperoleh pada stek daun utuh selama 39,54 hari yang tidak berbeda nyata dengan $1 / 2$ stek daun bagian pangkal selama 41,11 hari, tetapi berbeda nyata $1 / 2$ stek daun bagian ujung daun selama 43,90 hari. Sementara pada pengamatan persentasi stek hidup tertinggi diperoleh pada stek daun utuh sebesar $88,33 \%$ yang berbeda nyata dengan stek daun lainnya terutama pada $1 / 2$ stek daun bagian pangkal dengan persentasi stek hidup sebesar 71,67\%.

Tabel 2 menunjukkan bahwa pengaruh mandiri lama perendaman stek daun terhadap waktu munculnya tunas tercepat diperoleh pada lama perendaman stek

Tabel 1. Pengaruh mandiri stek daun pereromia pada lama perendaman rizobakteri terhadap pengamatan lama munculnya tunas dan persentasi tanaman hidup

\begin{tabular}{lccc}
\hline \multirow{2}{*}{ Perlakuan } & \multicolumn{3}{c}{ Variabel Pengamatan } \\
\cline { 2 - 4 } & Lama Munculnya Tunas (hari) & Persentasi Tanaman Hidup (\%) \\
\hline Daun utuh $\left(\mathrm{S}_{1}\right)$ & $39,544^{\mathrm{b}}$ & 88,33 & $\mathrm{a}$ \\
$1 / 2$ daun bagian pangkal $\left(\mathrm{S}_{2}\right)$ & $41,11^{\mathrm{ab}}$ & 71,67 & $\mathrm{~b}$ \\
$1 / 2$ daun bagian ujung $\left(\mathrm{S}_{3}\right)$ & $43,90^{\mathrm{a}}$ & 76,67 & $\mathrm{~b}$ \\
\hline
\end{tabular}

Keterangan: Angka-angka yang diikuti oleh huruf yang sama pada baris dan kolom yang sama berbeda tidak nyata pada uji DMRT $\alpha=0,05$

Tabel 2. Pengaruh mandiri lama perendaman stek daun dengan rizobakteri terhadap pengamatan lama munculnya tunas dan persentasi tanaman hidup

\begin{tabular}{lcc}
\hline \multirow{2}{*}{ Perlakuan } & \multicolumn{2}{c}{ Variabel Pengamatan } \\
\cline { 2 - 3 } & Lama Munculnya Tunas (hari) & Persentasi Tanaman Hidup (\%) \\
\hline Tanpa perendaman $\left(\mathrm{B}_{0}\right)$ & $46,30^{\mathrm{a}}$ & $68,89^{\mathrm{b}}$ \\
Perendaman 4 jam $\left(\mathrm{B}_{1}\right)$ & $37,28^{\mathrm{c}}$ & $86,67^{\mathrm{a}}$ \\
Perendaman 8 jam $\left(\mathrm{B}_{2}\right)$ & $40,19^{\mathrm{bc}}$ & $95,56^{\mathrm{a}}$ \\
Perendaman 12 jam $\left(\mathrm{B}_{3}\right)$ & $42,31^{\mathrm{b}}$ & $64,44^{\mathrm{b}}$ \\
\hline
\end{tabular}

Keterangan: Angka-angka yang diikuti oleh huruf yang sama pada baris dan kolom yang sama berbeda tidak nyata pada uji DMRT $\alpha=0,05$ 


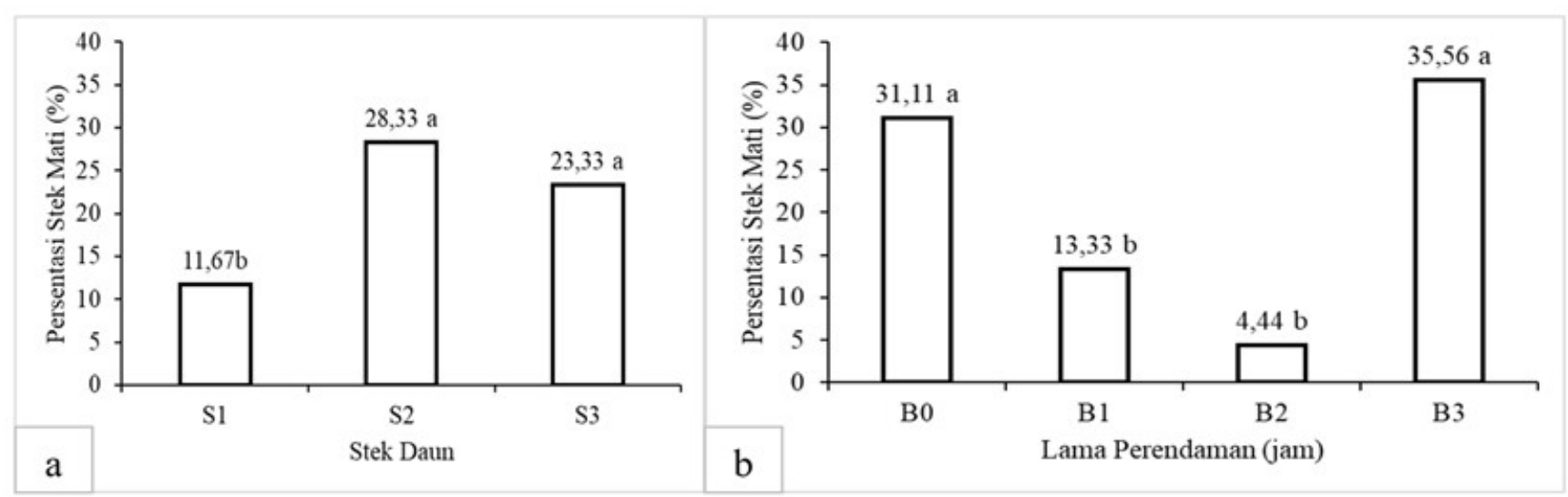

Gambar 1. Pengaruh bahan stek daun peperomia (a) dan lama perendaman (b) dalam rizobakteri pada pengamatan persentasi stek mati. Keterangan: Angka-angka yang diikuti oleh huruf yang sama pada baris dan kolom yang sama berbeda tidak nyata pada uji DMRT ${ }_{\alpha=0.05}$. S1 (daun utuh), S2 (1/2 daun bagian pangkal), S3 ( $1 / 2$ daun bagian ujung), B0 (tanpa perendaman), S1 (perendaman $4 \mathrm{jam}), \mathrm{S} 2$ (Perendaman 8 jam) dan S3 (perendaman 12 jam).

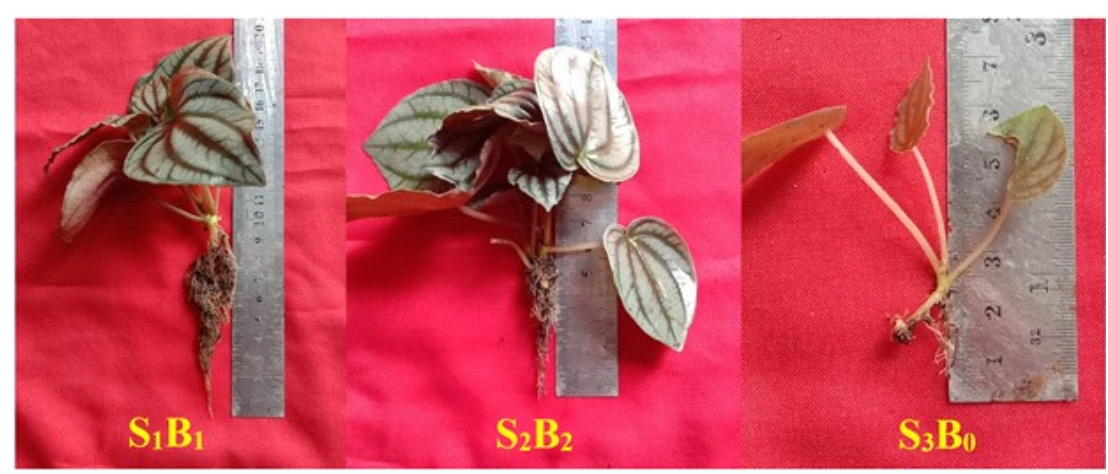

Gambar 2. Performa panjang akar tanaman P. turboensis pada perlakuan bahan stek dan lama perendaman dengan rizobakteri. Keterangan: $S_{1} B_{1}$ (daun utuh dengan lama perendaman 4 jam), $S_{2} B_{2}(1 / 2$ daun bagian pangkal dengan lama perendaman 8 jam $)$ dan $\mathrm{S}_{3} \mathrm{~B}_{0}(1 / 2$ daun bagian ujung daun dengan tanpa perendaman).

daun dengan rizobakteri selama 4 jam yaitu 37,28 hari yang tidak berbeda nyata dengan lama perendaman stek daun dengan rizobakteri selama 8 jam yaitu 40,19 hari, tetapi berbeda nyata dengan lama perendaman stek lainnya terutama tanpa perendaman stek selama 46,30 hari. Hasil pengamatan terhadap persentasi stek hidup tertinggi diperoleh pada lama perendaman stek dengan rizobakteri 8 jam sebesar 95,56\% yang tidak berbeda nyata dengan lama perendaman stek 4 jam sebesar $86,67 \%$ tetapi berbeda nyata dengan tanpa perendaman stek.
Gambar 1 menunjukkan bahwa pengaruh mandiri stek daun peperomia pada perendaman stek dalam rizobakteri terhadap persentasi stek mati tertinggi diperoleh pada $1 \frac{1}{2}$ stek daun bagian pangkal mencapai $28,33 \%$ yang tidak berbeda nyata dengan $1 / 2$ stek daun bagian ujung sebesar $23,33 \%$ tetapi berbeda nyata dengan stek daun utuh sebesar 11,67\%. Hal ini menunjukkan bahwa stek daun utuh memberikan hasil terhadap persentasi stek mati yang paling rendah.

Gambar 2 menunjukkan bahwa pengaruh mandiri lama perendaman stek daun dengan rizobakteri 
terhadap persentasi stek mati tertinggi diperoleh pada lama perendaman stek daun dengan rizobakteri selama 12 jam sebesar $35,56 \%$ yang tidak berbeda nyata dengan tanpa perendaman rizobakteri sebesar $31,11 \%$ tetapi berbeda nyata dengan lama perendaman stek daun dengan rizobakteri selama 4 jam sebesar 13,33\% dan lama perendama stek daun dengan rizobakteri selama 8 jam sebesar 4,44\%. Hal ini menunjukkan bahwa perendaman stek daun dengan rizobakteri mampu menekan persentasi stek mati.

Tabel 3 menunjukkan bahwa interaksi perlakuan stek daun pada berbagai perlakuan lama perendaman dengan rizobakteri terhadap jumlah tunas tertinggi diperoleh pada interaksi perlakuan daun utuh dengan perendaman 4 jam sebanyak 2, 11 tunas yang berbeda nyata dengan interaksi perlakuan daun utuh dengan tanpa perendaman, $1 / 2$ daun bagian pangkal dengan tanpa perendaman, $1 / 2$ daun bagian ujung dengan tanpa perendaman, $1 / 2$ daun bagian ujung dengan perendaman 8 jam dan $1 / 2$ daun bagian ujung dengan perendaman 12 jam tetapi tidak berbeda nyata dengan perlakuan lainnya. Hasil interaksi perlakuan stek daun pada berbagai perlakuan lama perendaman dengan rizobakteri terhadap panjang akar diperoleh pada interaksi perlakuan daun utuh dengn perendaman 4 jam sebesar $\mathrm{cm}$ yang tidak berbeda nyata dengan interaksi perlakuan $1 \frac{1}{2}$ daun bagian pangkal dengan perendaman 4 jam dan perlakuan daun utuh dengn perendaman 8 jam tetapi berbeda nyata dengan interaksi perlakuan lainnya.

\section{Pembahasan}

Hasil penelitian ini menunjukkan bahwa penggunaan stek daun pada daun utuh memberikan hasil terbaik dibandingkan dengan stek daun lainnya (Tabel 1). Hal ini diduga karena pada daun utuh terdapat pelukaan yang lebih sedikit sehingga berpengaruh terhadap lama pemunculan tunas dan persentasi stek hidup. Sementara pada $1 / 2$ daun bagian pangkal dan $1 / 2$ daun bagian ujung daun terdapat pelukaan yang relatif lebih besar sehingga dapat mempengaruhi laju infeksi dari patogen. Selain itu, ketersediaan cadangan makanan pada dauh utuh lebih banyak dibandingkan dengan daun yang dipotong $1 / 2$.

Hasil penelitian menunjukkan bahwa penggunaan lama perendaman dengan rizobakteri pada stek daun tanaman peperomia memberikan hasil yang

Tabel 3. Pengaruh interaksi stek daun dan lama perendaman dengan rizobakteri terhadap jumlah tunas dan panjang akar tanaman peperomia

\begin{tabular}{|c|c|c|c|c|}
\hline \multirow[b]{2}{*}{ Stek Daun } & \multicolumn{4}{|c|}{ Lama Perendaman } \\
\hline & Tanpa Perendaman $\left(\mathrm{B}_{0}\right)$ & $4 \mathrm{jam}\left(\mathrm{B}_{1}\right)$ & 8 jam $\left(B_{2}\right)$ & $12 \mathrm{jam}\left(\mathrm{B}_{3}\right)$ \\
\hline & \multicolumn{4}{|c|}{ Jumlah Tunas } \\
\hline Daun utuh $\left(\mathrm{S}_{1}\right)$ & $1,00^{\mathrm{d}}$ & $2,11^{a}$ & $1,78^{a b}$ & $1,61^{\mathrm{abc}}$ \\
\hline $1 / 2$ daun bagian pangkal $\left(\mathrm{S}_{2}\right)$ & $1,00^{\mathrm{d}}$ & 1,67 abc & $2,00^{\text {a }}$ & $1,67^{\mathrm{abc}}$ \\
\hline \multirow[t]{2}{*}{$1 / 2$ daun bagian ujung $\left(\mathrm{S}_{3}\right)$} & $1,17 \mathrm{~cd}$ & 1,61 abc & 1,28 bcd & $1,00^{\mathrm{d}}$ \\
\hline & \multicolumn{4}{|c|}{ Panjang Akar } \\
\hline Daun utuh $\left(\mathrm{S}_{1}\right)$ & $3,50^{\mathrm{c}}$ & $8,93^{\mathrm{a}}$ & $7,87^{\mathrm{a}}$ & $5,93^{\mathrm{b}}$ \\
\hline $1 / 2$ daun bagian pangkal $\left(S_{2}\right)$ & $3,27^{\mathrm{c}}$ & $7,57^{\text {a }}$ & 5,93 b & $5,43^{\mathrm{b}}$ \\
\hline 1/2 daun bagian ujung $\left(\mathrm{S}_{3}\right)$ & $2,63^{\mathrm{c}}$ & 4,80 bc & 4,60 bc & $3,50^{\mathrm{c}}$ \\
\hline
\end{tabular}

Keterangan: Angka-angka yang diikuti oleh huruf yang sama pada baris dan kolom yang sama berbeda tidak nyata pada uji DMRT $\alpha=0,05$ 
lebih baik pada perendaman 4 dan 8 jam perendaman tetapi tidak memberikan hasil yang lebih baik terhadap perendaman 12 jam (Tabel 2) dan juga tanpa perendaman agens hayati. Hal ini menunjukan bahwa lama perendaman berpengaruh terhadap daya serap air dalam tanaman hias peperomia sehingga berakibat pada kebusukan awal dari tanaman peperomia yang berpengaruh pada persentasi hidup tanaman peperomia. Perendaman stek daun dengan rizobakteri selama 4 dan 8 memberikan hasil terbaik, hal ini berkaitan langsung dengan kemampuan rizobakteri yang mampu menghasilkan senyawa antibiotik yang dapat menghambat perkembangan patogen. Hal ini didukung oleh penelitian Agustiansyah et al. (2013) bahwa agens hayati mampu menghasilkan senyawa siderofor yang mampu menghambat perkembangan patogen akibat persaingan perebutan unsur Fe yang merupakan nutrisi bagi patogen. Mulyadi(2018) juga melaporkan bahwa, nilai rerata setiap pengamatan pada perlakuan pengaplikasian PGPR pada perendaman benih lebih baik dibandingkan dengan pemberian 1 hari sebelum inokulasi dan 15 hari setelah inokulasi ketika tanaman sudah terinfeksi oleh SMV.

Mekanisme rizobakterimengendalikan penyakit dapat melalui beberapa cara yaitu melalui produksi senyawa antibiosis, persaingan ruang atau nutrisi, persaingan pemanfaatan unsur Fe melalui produksi senyawa siderofor, induksi mekanisme ketahanan, memalui inaktivasi perkecambahan kecambah dan produksi toksin, parasitisme yang melibatkan enzim pedegradasi dinding sel seperti enzim kitinase, â-1.3 glukanase (Van Loon, 2007). Lebih lanjut, bahwa mekanisme PGPR sebagai agens pengendali hayati dapat melalui resistensi sistemik, pemanfaatan Fe, ruang dan persaingan hara, sintesis antibiotik, produksi asam litik dan hidrogen sianida (Odoh and Chukc, 2017; Khotchanalekha et al., 2020; Resti et al., 2020). Selain itu rizobakteri yang digunakan dalam penelitian ini mampu menghasilkan hormon tumbuh berupa IAA. Astriani dan Murtiyaningsih (2018) melaporkan bahwa kandungan IAA yang dihasilkan Bacillus sp. tergolong cukup tinggi untuk dapat diaplikasikan sebagai bakteri pemacu pertumbuhan tanaman (PGPR).

Hasil penelitian ini menunjukkan bahwa secara mandiri stek daun utuh memberikan hasil terbaik kemudian diikuti perlakuan $1 / 2$ daun bagian pangkal. Sementara berdasarkan lama perendaman dengan rizobakteri, lama perendaman 8 dan 4 jam memberikan hasil terbaik bila dibandingkan dengan lama perendaman 12 jam dan tanpa perendaman. Untuk interaksi perlakuan terbaik diperoleh ada perlakuan daun utuh dengan perendaman 4 jam dan perlakuan $1 / 2$ daun bagian pangkal dengan perendaman 8 jam dengan menghasilkan jumlah tunas terbanyak dan panjang akar tanaman (Tabel 3). Peningkatan ini berkaitan dengan produksi IAA oleh rizobakteri. Asam indol asetat (IAA) merupakan salah satu hormon pertumbuhan tanaman yang berperan penting dalam menstimulasi pertumbuhan tanaman. Peran IAA yang diproduksi eksogen dari bakteri mampu mempercepat pertumbuhan tanaman dalam memacu proses diferensiasi pada akar dalam membentuk rambut akar (Herlina et al., 2017; Bhutani et al., 2018). Selanjutnya, sintesis hormon IAA oleh bakteri berperan meningkatkan pertumbuhan tanaman (Aryantha et al., 2004; Santoyo et al., 2016; Afa et al., 2020). 


\section{KESIMPULAN}

Hasil penelitian ini menunjukkan bahwa secara mandiri stek daun utuh memberikan hasil terbaik terhadap pengamatan waktu munculnya tunas, persentasi tanaman hidup dan persentasi tanaman mati kemudian diikuti bahan stek $1 / 2$ daun bagian pangkal. Perlakuan lama perendaman 4 dan 8 jam memberikan hasil terbaik bila dibandingkan dengan lama perendaman 12 jam dan tanpa perendaman. Interaksi perlakuan terbaik diperoleh pada perlakuan daun utuh dengan perendaman 4 jam baik pada pengamatan jumlah tunas maupun panjang akar, kemudian diikuti perlakuan $1 / 2$ daun bagian pangkal dengan perendaman 8 jam pada pengamatan jumlah tunas dan perlakuan $1 / 2$ daun bagian pangkal dengan perendaman 4 jam dan daun utuh dengan perendaman 8 jam pada pengamatan panjang akar.

\section{UCAPAN TERIMA KASIH}

Ucapan terima kasih kami sampaikan kepada Lembaga Penelitian dan Pengabdian Kepada Masyarakat Universitas Halu Oleo melalui dana Hibah

\section{DAFTAR PUSTAKA}

Advinda, L., M. Fifendy, A. Anhar, I. Leilani dan A.L. Sahara. 2018. Pertumbuhan stek horizontal batang jarak pagar (Jatropha curcas L.) yang diintroduksi dengan Pseudomonad fluoresceens. Eksakta. 19(1): 65-79. DOI: 10.24036/eksakta/vol19-iss01/129.

Afa M, Sadimantara IGR, R ahni NM and Sutariati GAK. 2020. Isolation \& characterization of rhizobacteria from local shallots rhizosphere as promoting growth of shallot (Allium
Ascalonicum L.). International Journal of Scientific \& Technology Research. 9(3): 3228-3233.

Agustiansyah, S. Ilyas, Sudarsono dan M. Machmud. 2013. Karakterisasi rizobakteri yang berpotensi mengendalikan bakteri Xanthomonas oryzae pv. oryzae dan meningkatkan pertumbuhan tanaman padi. $J$. HPT Tropika. 13(1): $42-51$.

Aryantha, I.N., D.P. Lestari dan N.P.D. Pangesti. 2004. Potensi isolat bakteri penghasil IAA dalam peningkatan pertumbuhan kecambah kacang tanah pada kondisi hidroponik. Jurnal Mikrobiologi Indonesia. 9(2): 43 - 46.

Astriani, M. dan H. Murtiyaningsih. 2018. Pengukuran indole-3-acetic acid (IAA) pada Bacillus sp. dengan penambahan L-Tryptofan. Bioeduscience. 2(2): 116-121. Doi:https:// doi.org/10.29405/j.bes/22116-1212233 .

Bhutani, N., R. Maheshwari, N. Monika \& S.D. Pooja. 2018. Optimization of IAA production by endophytic Bacillus spp. from Vigna radiata for their potential use as plant growth promoters. Israel Journal of Plant Sciences, 65. 10.1163/22238980-00001025.

Chuks, K.O., C.N. Eze, U.K. Akpi and V.U. Unah. 2018. Plant growth promoting rhizobacteria (PGPR): a novel agent for sustainable food production. American Journal of Agricultural and Biological Sciences. DOI:http://dx.doi.org/10.22192/ ijarbs.2017.04.05.014.

Elango, R, R. Parthasarathi and S. Megala. 2013. Field level studies on the association of plant growth promoting rhizobacteria (PGPR) in Gloriosa 
Superba L. rhizosphere. Indian Streams Research Journal, 3(10): 1-6.

Flores-Gallegos, A.C. and E. Nava-Reyna. 2019. Plant Growth-Promoting Microbial Enzymes. Enzymes in Food Biotechnology Production, Applications, and Future Prospects. Academic Press. Pp. 521-534. https://doi.org/10.1016/B978-0-12-8132807.00030-X.

Guyasa, I.M., I.G.R. Sadimantara, A. Khaeruni \& G.A.K. Sutariati. 2018. Isolation of Bacillus spp. and Pseudomonas fluorescens from upland rice rhizosphere and its potential as plant growth promoting rhizobacteria for local upland rice (Oryza sativa L.). Bioscience Research. 5(4): 3231-3139.

Herlina, L., K.K. Pukan and D. Mustikaningtyas. 2017. The endophytic bacteria producing IAA (Indole Acetic Acid) in Arachis hypogaea. Cell Biology \& Development. 1(1): 31-35. DOI: https://doi.org/10.13057/cellbioldev/ v010106.

Khotchanalekha K., W. Saksirirat, S.I. Na Ayutthaya, K. Sakai, Y. Tashiro, Y. Okugawa \& S. Tongpim. 2020. Isolation and selection of plant growth promoting endophytic bacteria associated with healthy hevea brasiliensis for use as plant growth promoters in rubber seedlings under salinity stress. Chiang Mai Journal of Science. 47(1): 39-48.

Mudi, L., A. Bahrun dan G.A.K. Sutariati. 2018. BioPriming benih menggunakan campuran rizobakter indigenous untuk meningkatkan kualitas fisiologis benih kedelai (Glycine max L. Merril). J. Berkala Penelitian Agronomi. 6(1): 1-8. DOI: http://dx.doi.org/10.33772/ bpa.v6i1.7508.
Mulyadi, B.R. 2018. Penggunaan Plant Growth Promoting Rhizobacteria (PGPR) Sebagai Agens Proteksi Dalam Mekanisme Ketahanan Terinduksi Terhadap Infeksi Soybean Mosaic Virus (Smv) Pada Tanaman Kedelai (Glycine max L.) Varietas Anjasmoro. Sarjana Thesis, Universitas Brawijaya. Malang.

Odoh and K. Chuks. 2017. Plant growth promoting rhizobacteria (PGPR): a bioprotectant bioinoculant for sustainable agrobiology. A Review. Int. J. Adv. Res. Biol. Sci. 4(5): 123142.

Patel, T. \& M. Saraf. 2017. Biosynthesis of phytohormones from novel rhizobacterial isolates and their in vitro plant growthpromoting efficacy. Journal of Plant Interactions. 12(1): 480-487. DOI: 10.1080/ 17429145.2017.1392625.

Resti, Z., Y. Liswarni, \& M. Martinius. 2020. Endophytic bacterial consortia as biological control of bacterial leaf blight and plant growth promoter of rice (Oryza sativa L.). Journal of Applied Agricultural Science and Technology. 4(2): 134-145. https://doi.org/ $\underline{10.32530 / \text { jaast.v4i2.146. }}$.

Santoyo G., G. Moreno-Hagelsieb, M.C. OrozcoMosqueda and B.R. Glick. 2016. Plant growth-promoting bacterial endophytes. Microbiological Research. 183: 92-99. https:/ /doi.org/10.1016/j.micres.2015.11.008.

Silaban, I.C., L.Q. Aini and M.A. Syib'li. 2015. Pengujian konsorsium mikroba antagonis untuk mengendalikan jamur Sclerotium rolfsii penyebab penyakit rebah semai pada kedelai (Glycine max L.). J Hama dan Penyakit Tumbuhan. 3(2): 100. 
Stanojkoviæ-Sebiæ, A, R. Piviæ, Z. Diniæ, R. Ilièiæ, D. Latkoviæ and D. Jošiæ. 2018. Effect of indigenous Pseudomonas sp. and Bacillus sp. strains on yield and main chemical growth parameters of radicchio. The Serbian Journal of Agricultural Science. 67(1): 20-26.

Sutariati, G.A.K., A. Khaeruni, Muhidin, A. Madiki, T.C. Rakian, L. Mudi and N. Fadillah. 2019. Seed biopriming with indigenous endophytic bacteria isolated from Wakatobi rocky soil to promote the growth of onion (Allium ascalonicum L.). IOP Conference Series: Earth and Environmental Science 260. Doi:10.1088/1755-1315/260/1/012144. IOP Publishing.
Sutariati, G.A.K., N.M. Rahni, A. Madiki and I.M. Guyasa. 2020. Characterization of endophyticrhizobacteria from areca nut rhizosphere to dissolve phosphates, nitrogen fixation of IAA hormone synthesis. Pakistan journal of biological sciences: PJBS. 23(3): 240-247.

Sutariati, GA.K., T.C. Rakian, A. Khaeruni and Ratna. 2018. The potential of indigenous rhizobacteria isolated from Wakatobi rocky soil as plant growth promoting of onions. Bioscience Research. 15(4): 3755-3761.

Van Loon LC. 2007. Plant response to plant growth promoting rhizobacteria. Eur. J. Plant Pathol., 119:243-254. 